\title{
GMR
}

\section{High genetic diversity of Jatropha curcas assessed by ISSR}

\author{
B.G. Díaz ${ }^{1}$, D.M. Argollo', M.C. Franco${ }^{1}$, S.M. Nucci', W.J. Siqueira', \\ D.M. de Laat $^{2}$ and C.A. Colombo ${ }^{1}$ \\ ${ }^{1}$ Centro de Pesquisa e Desenvolvimento de Recursos Genéticos Vegetais, \\ Instituto Agronômico de Campinas, Campinas, SP, Brasil \\ ${ }^{2}$ Centro de Grãos e Fibras, Instituto Agronômico de Campinas, \\ Campinas, SP, Brasil \\ Corresponding authors: B.G. Díaz / C.A. Colombo \\ E-mail: diaz.brenda01@gmail.com / ccolombo@iac.sp.gov.br
}

Genet. Mol. Res. 16 (2): gmr16029683

Received March 23, 2017

Accepted May 5, 2017

Published May 31, 2017

DOI http://dx.doi.org/10.4238/gmr16029683

Copyright (C) 2017 The Authors. This is an open-access article distributed under the terms of the Creative Commons Attribution ShareAlike (CC BY-SA) 4.0 License.

\begin{abstract}
Jatropha curcas L. is a highly promising oilseed for sustainable production of biofuels and bio-kerosene due to its high oil content and excellent quality. However, it is a perennial and incipiently domesticated species with none stable cultivar created until now despite genetic breeding programs in progress in several countries. Knowledge of the genetic structure and diversity of the species is a necessary step for breeding programs. The molecular marker can be used as a tool for speed up the process. This study was carried out to assess genetic diversity of a germplasm bank represented by $J$. curcas accessions from different provenance beside interspecific hybrid and backcrosses generated by IAC breeding programs using inter-simple sequence repeat markers. The molecular study revealed 271 bands of which $98.9 \%$ were polymorphic with an average of 22.7 polymorphic bands per primer. Genetic diversity of the germplasm evaluated was slightly higher than other germplasm around the world and ranged from 0.55 to 0.86 with an average of 0.59 (Jaccard index). Cluster analysis (UPGMA) revealed no clear grouping as to the geographical origin of accessions, consistent
\end{abstract}

Genetics and Molecular Research 16 (2): gmr16029683 
with genetic structure analysis using the Structure software. For diversity analysis between groups, accessions were divided into eight groups by origin. Nei's genetic distance between groups was 0.14 . The results showed the importance of Mexican accessions, congeneric wild species, and interspecific hybrids for conservation and development of new genotypes in breeding programs.

Key words: Jatropha curcas; Jatropha integerrima; Interspecific hybrids; Physic nut; Molecular marker; Plant breeding

\section{INTRODUCTION}

Jatropha curcas L. (Euphorbiaceae) is a perennial tree, monoecious with unisexual flowers (Montes and Melchinger, 2016). Probably native to Mexico (Pecina-Quintero et al., 2014) this species occurs in tropical and subtropical regions of the world, and it is considered one of the most promising oilseeds for biodiesel production due to the high oil content of oilseeds, reaching 40 to $50 \%$ (Subramanian et al., 2005). The yield ranges from 0.3 to $3000 \mathrm{~kg}$ seeds/ha. It is adapted to different environmental conditions, including low rainfall and lowfertility soil, and does not compete with food crops (Montes and Melchinger, 2016).

Despite the promise, J. curcas is an incipiently domesticated species with no availability of stable and commercial cultivars with high oil content and tolerant to pests and diseases that can meet the needs of farmers and processors of the feedstock produced. Therefore, the establishment of $J$. curcas as a commercially viable culture requires the development of a suitable genetic breeding program (Argollo Marques et al., 2013).

J. curcas is a xenogamic plant, highly heterozygous for most characteristics, which implies a high degree of segregation. Consequently, breeding programs require several years to obtain a cultivar. Biotechnological techniques such as tissue culture, genetic engineering, and molecular genetic analysis can be integrating into breeding programs to shorten this time (Argollo Marques et al., 2013).

Genetic diversity is defined as the variety of alleles or genotypes in a given population and may be reflected in morphological, physiological, and behavioral differences among individuals and populations. The establishment of a germplasm bank representing the genetic variability of the species (core collection) is essential to the success of the breeding program.

Assessment of genetic diversity in $J$. curcas germplasm has been carried out by morphological markers (Montes Osorio et al., 2014; Pazeto et al., 2015). Other authors have found large variations in chemical and morphological traits including oil content (27.8-39.0\%) and seed weight (44-79 g) in Indian accessions from different geographical origins (Rao et al., 2008). Brazilian accessions have shown variability in plant size, fruits per bunch, the content of oil and phorbol esters, and fatty acid composition (Argollo Marques et al., 2013). Nevertheless, environmental effects can influence the expression of the traits, altering the efficiency of such markers. In turn, molecular markers (specific DNA segments that are representative of differences at genomic level) allow the exploration of genetic polymorphism between individuals, whether or not correlated with phenotypic expression, because they are not affected by the environment or by pleiotropic effects or epistasis (Mondini et al., 2009).

Molecular markers like RAPD (randomly amplified polymorphic DNA), AFLP (amplified fragment length polymorphism), SSR microsatellites (simple sequence repeat), ISSR

Genetics and Molecular Research 16 (2): gmr16029683 
(inter-simple sequence repeat), among others have been employed to assess genetic diversity in $J$. curcas germplasm from different parts of the world (Basha and Sujatha, 2007; Ganesh-Ram et al., 2008; Grativol et al., 2011; Tanya et al., 2011; Sudheer et al., 2011; Montes et al., 2014; PecinaQuintero et al., 2014). Most of these studies have reported narrow diversity in germplasm (Basha and Sujatha, 2007; Sun et al., 2008; Shen et al., 2010), independent from the marker system used, which indicate the need to broaden the genetic base in these countries. Assessing genetic variation by RAPD, AFLP, and combinatorial tubulin-based polymorphism (cTBP) in $38 \mathrm{~J}$. curcas accessions from 13 countries on 3 continents revealed narrow genetic diversity. However, 6 different species of Jatropha from India exhibited pronounced genetic diversity indicating possibilities of improving $J$. curcas by interspecific breeding (Popluechai et al., 2009). On the other hand, wide genetic diversity has been observed in materials from Mexico and other countries of Central America (Pamidimarri and Muppala, 2014; Pecina-Quintero et al., 2014; Santos et al., 2016).

In Brazil, some studies using ISSR markers (Grativol et al., 2011) and cTBP markers (Breviario et al., 2007) revealed reduced genetic diversity within and between Brazilian accessions from different origins. In contrast, Pioto et al. (2015) and Rosado et al. (2010) using AFLP and RAPD markers, respectively, reported low genetic diversity on accessions from São Paulo and other Brazilian states.

The lack of genetic diversity in most of the countries where Jatropha is distributed is implicated in the slowing of progress in developing new Jatropha cultivars with improved yield and quality potential. To broad the Jatropha genetic base, this may be accomplished by a collection of available germplasm or by the introgression of new genetic materials (genes) through inter- and intra-specific hybridization that will increase the genetic base and allow the development of new cultivars (Argollo Marques et al., 2013). The present study aimed to assess genetic diversity of elite $J$. curcas germplasm for breeding purposes using molecular markers. The results will allow understanding the genetic relationships among elite accessions from IAC (Agronomic Institute of São Paulo State) germplasm bank for guiding crossing and aid the creation of new genotypes. Besides, the evaluation of the system markers would help in future studies to rapidly evaluate the breeding material.

\section{MATERIAL AND METHODS}

We analyzed 66 genotypes comprising 56 accessions of $J$. curcas previously shown to be phenotypically diverse, one F1 interspecific hybrid (J. curcas $\mathrm{x} J$. integerrima) and 8 backcrosses of $J$. curcas $/ J$. curcas $J$. integerrima, and the congeneric species $J$. integerrima. All accessions belong to physic nut germplasm of IAC located at Campinas, SP (Table 1).

\section{DNA extraction}

Genomic DNA was isolated from young leaves pulverized in N2 liquid using the CTAB protocol described by Doyle and Doyle (1990). Approximately $100 \mathrm{mg}$ plant tissue was suspended in $800 \mu \mathrm{L}$ extraction buffer $(1.4 \mathrm{M} \mathrm{NaCl}, 20 \mathrm{mM}$ EDTA, pH 8.0, $100 \mathrm{mM}$ Tris-HCl, $\mathrm{pH} 8.0,1 \%$ Polyvinylpyrrolidone MW 10,000, $2 \%$ CTAB and $0.2 \% \beta$-mercaptoethanol) and incubated at $65^{\circ} \mathrm{C}$ for $60 \mathrm{~min}$. Then, we added $800 \mu \mathrm{L}$ chloroform/isoamyl alcohol $24: 1(\mathrm{v} / \mathrm{v})$ and centrifuged at $10,000 \mathrm{~g}$ for $10 \mathrm{~min}$. This step was performed twice. DNA was precipitated with $70 \%(\mathrm{v} / \mathrm{v})$ ice-cold isopropanol and centrifuged for $10 \mathrm{~min}$ at $10,000 \mathrm{~g}$. The pellet was washed with $1 \mathrm{~mL} \mathrm{70 \%} \mathrm{ethanol} \mathrm{and} \mathrm{dried} \mathrm{at} \mathrm{room} \mathrm{temperature.} \mathrm{DNA} \mathrm{was} \mathrm{suspended} \mathrm{in} 50 \mu \mathrm{L}$

Genetics and Molecular Research 16 (2): gmr16029683 
TE buffer (10 mM Tris-HCl, $\mathrm{pH} 8.0$, and $1 \mathrm{mM}$ EDTA). The integrity of the DNA extracted was evaluated on $1 \%$ agarose gel and the quantity determined by NanoVue spectrophotometer (GE Healthcare).

\begin{tabular}{|c|c|c|c|c|c|c|c|}
\hline ID & Genotype & Location & Group & ID & Genotype & Location & Group \\
\hline 1 & J. integerrima & Unknown & Wild & 34 & L12P8 & Minas Gerais & Brazil southeast \\
\hline 2 & L6P7 & Mato Grosso do Sul & Brazil midwest & 35 & L12P9 & Minas Gerais & Brazil southeast \\
\hline 3 & L6P25 & Mato Grosso do Sul & Brazil midwest & 36 & L4P44 & São Paulo & Brazil southeast \\
\hline 4 & L6P31 & Mato Grosso do Sul & Brazil midwest & 37 & L4P50 & São Paulo & Brazil southeast \\
\hline 5 & L12P41 & Tocantins & Brazil midwest & 38 & L13P48 & Sao Paulo & Brazil southeast \\
\hline 6 & L13P30 & Pernambuco & Brazil northeast & 39 & L3P29 & São Paulo & Brazil southeast \\
\hline 7 & PARÁ6 & Pará & Brazil northeast & 40 & L2P21 & São Paulo & Brazil southeast \\
\hline 8 & L8P54 & Bahia & Brazil northeast & 41 & L3P27 & São Paulo & Brazil southeast \\
\hline 9 & PARÁ5 & Pará & Brazil northeast & 42 & L5P48 & São Paulo & Brazil southeast \\
\hline 10 & L13P20 & Pernambuco & Brazil northeast & 43 & L11P7 & São Paulo & Brazil southeast \\
\hline 11 & L13P25 & Pernambuco & Brazil northeast & 44 & L12P23 & Minas Gerais & Brazil southeast \\
\hline 12 & L12P51 & Pernambuco & Brazil northeast & 45 & L12P29 & Minas Gerais & Brazil southeast \\
\hline 13 & L13P4 & Pernambuco & Brazil northeast & 46 & \begin{tabular}{|l|} 
L13P55 \\
\end{tabular} & São Paulo & Brazil southeast \\
\hline 14 & L9P1 & Bahia & Brazil northeast & 47 & L17U8(3) & São Paulo & Brazil southeast \\
\hline 15 & L9P32 & Bahia & Brazil northeast & 48 & L17U5(2) & São Paulo & Brazil southeast \\
\hline 16 & L8P29 & Bahia & Brazil northeast & 49 & L14P1 & São Paulo & Brazil southeast \\
\hline 17 & L2P39-A & Fortaleza & Brazil northeast & 50 & L9P51 & Minas Gerais & Brazil southeast \\
\hline 18 & L12P57 & Fortaleza & Brazil northeast & 51 & L2P7-A & China & China \\
\hline 19 & L13P9 & Pernambuco & Brazil northeast & 52 & L1P40-A & China & China \\
\hline 20 & L13P46 & Pernambuco & Brazil northeast & 53 & MÉXICO-A4 & Mexico & Mexico \\
\hline 21 & L9P44 & Minas Gerais & Brazil southeast & 54 & MÉXICO-A3 & Mexico & Mexico \\
\hline 22 & L9P49 & São Paulo & Brazil southeast & 55 & MÉXICO-A20 & Mexico & Mexico \\
\hline 23 & L6P11 & São Paulo & Brazil southeast & 56 & MÉXICO-A10 & Mexico & Mexico \\
\hline 24 & L12P52 & São Paulo & Brazil southeast & 57 & MÉXICO-A5 & Mexico & Mexico \\
\hline 25 & L4P49 & São Paulo & Brazil southeast & 58 & RC1F1-1 & Backcross & Breeding program \\
\hline 26 & L4P19 & São Paulo & Brazil southeast & 59 & RC1F1-91 & Backcross & Breeding program \\
\hline 27 & L2P23 & São Paulo & Brazil southeast & 60 & RC1F1-74 & Backcross & Breeding program \\
\hline 28 & L2P19 & São Paulo & Brazil southeast & 61 & RC1F1-25 & Backcross & Breeding program \\
\hline 29 & L1P7 & São Paulo & Brazil southeast & 62 & RC1F1-9 & Backcross & Breeding program \\
\hline 30 & L10P5 & Minas Gerais & Brazil southeast & 63 & RC1F1-64 & Backcross & Breeding program \\
\hline 31 & L12P4 & São Paulo & Brazil southeast & 64 & RC1F1-37 & Backcross & Breeding program \\
\hline 32 & L12P2 & São Paulo & Brazil southeast & 65 & RC1F1-100 & Backcross & Breeding program \\
\hline 33 & L11P5 & São Paulo & Brazil southeast & 66 & Hybrid F1 & J. curcas/J. intergerrima & Breeding program \\
\hline
\end{tabular}

\section{ISSR analysis}

Ten ISSR primers previously shown to be polymorphic for $J$. curcas were used for the genotyping (Table 2). PCRs were performed in a final volume of $20 \mu \mathrm{L}$ containing $40 \mathrm{ng}$ DNA, $1 X$ buffer (10 mM Tris-HCl, pH 8.3, $50 \mathrm{mM} \mathrm{KCl}), 0.25 \mathrm{mM}$ dNTPs, $2.5 \mathrm{mM} \mathrm{MgCl}$, $0.25 \mathrm{mM}$ of each primer, and $1 \mathrm{U}$ Taq polymerase (Fermentas, MBI). PCRs were run with initial denaturation at $94^{\circ} \mathrm{C}$ for $1 \mathrm{~min}$, followed by 35 cycles of denaturation at $94^{\circ} \mathrm{C}$ for $45 \mathrm{~s}$, $45 \mathrm{~s}$ annealing at $48^{\circ}-56.5^{\circ} \mathrm{C}$ depending on the primer, a 1 min extension at $72^{\circ} \mathrm{C}$, and finally $72^{\circ} \mathrm{C}$ for $5 \mathrm{~min}$. Amplified products were analyzed by electrophoresis on $1.5 \%$ agarose gel in $0.5 \mathrm{X}$ TBE buffer, $\mathrm{pH}$ 8.3. Gene Ruler Mix of 1000 bp (Fermentas, USA) was used as a molecular weight marker. DNA fragments were visualized under UV light on an AlphaImager photodocumentation system (AlphaImager System for Cell HP ${ }^{\circledR}$ Biosciences).

\section{Data analysis}

The profiles of ISSR markers were scored for band presence (1) or absence (0) to create a binary matrix used to calculate the Jaccard similarity coefficient. Dendrograms 
were constructed using the UPGMA method (unweighted pair group method with arithmetic average) in NTSYS-pc 2.2 (Rohlf, 1989).

Genetic diversity measures were calculated among genotypes and between groups (populations) formed according to accession origin (Table 1). Genetic diversity was calculated using the Nei's index $(H)$ and Shannon index $(I)$, and obtained values of total heterozygosity $\left(H_{\mathrm{T}}\right)$, mean heterozygosity within populations $\left(H_{\mathrm{S}}\right)$, diversity among populations $\left(D_{\mathrm{ST}}\right)$, coefficient of population differentiation $\left(G_{\mathrm{ST}}\right)$, and gene flow $(N \mathrm{~m})$, using the POPGENE software 1.3.2 (Yeh et al., 1999).

The STRUCTURE software 2.3 (Pritchard et al., 2000) was used to define the most likely number of groups $(\mathrm{K})$ in the samples. The determination of the K number was based on 50,000 Markov Chain Monte Carlo simulations; with burn-in of 500,000 and 20 interactions for each group $(\mathrm{K})$, ranging from one to ten. The most apparent determination with the proposed ones was performed using $\Delta \mathrm{K}$, according to Evanno et al. (2005), using the Structure Harvester tool (Earl and VonHoldt, 2012).

\section{RESULTS}

\section{ISSR polymorphism analysis}

Ten ISSR combinations produced 271 polymorphic bands, with $98 \%$ of them polymorphic. The number of polymorphic bands per primer ranged from 11 (MANNY) to 37 (ISSR1 and ISSR3), with an average of 22.7 (Table 2), with amplification products ranging from 100 to $2500 \mathrm{bp}$. An example of the ISSR profile is shown in Figure 1.

Table 2. Primer sequence, annealing temperature, and polymorphic bands of ISSR primers used to assess the genetic diversity of Jatropha spp.

\begin{tabular}{l|l|c|c|c}
\hline ISSR primer & Primer sequence $\left(5^{\prime}-3^{\prime}\right)$ & Annealing temperature $\left({ }^{\circ} \mathrm{C}\right)$ & Polymorphic bands $(\mathrm{PB})$ & $\%$ \\
\hline ISSR 1 & AGAGAGAGAGAGAGAGT & 53.0 & 3 & 97.3 \\
\hline ISSR 2 & AGAGAGAGAGAGAGAGYT & 48.0 & 23 & 100 \\
\hline ISSR 3 & AGAGAGAGAGAGAGAGYA & 53.0 & 37 & 97.3 \\
\hline ISSR 5 & ACACACACACACACACYA & 56.5 & 18 & 100 \\
\hline ISSR 6 & GACAGACAGACAGACA & 53.6 & 17 & 100 \\
\hline ISSR 7 & DBDACACACACACACACAC & 48.2 & 16 & 100 \\
\hline ISSR 898 & CACACACACACARY & 52.0 & 11 & 94.2 \\
\hline OMAR & GAGGAGGAGGAGRC & 52.0 & 19 & 100 \\
\hline MANNY & CACCACCACCACRC & 52.0 & & 100 \\
\hline TERRY & GTGGTGGTGGTGRC & 52.0 & & \\
\hline
\end{tabular}

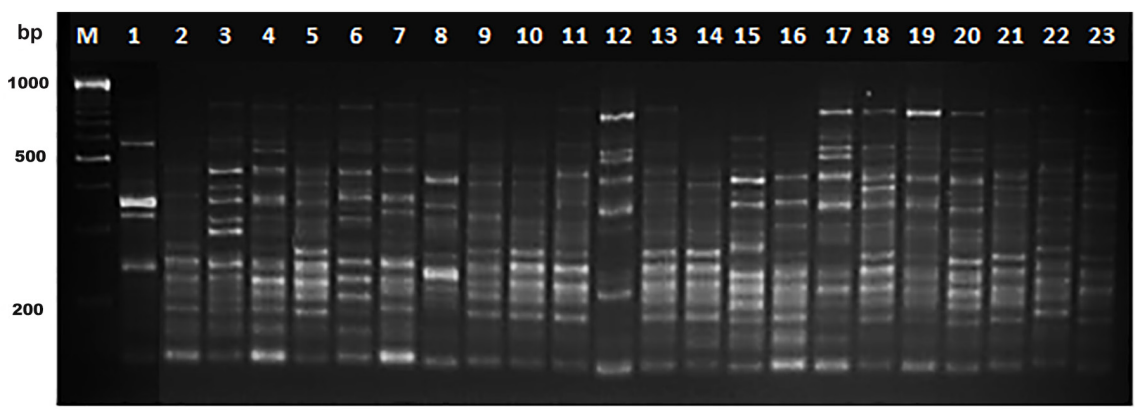

Figure 1. ISSR profile of the 23 accessions of Jatropha spp (lanes 1-23) shown in Table 1 and amplified by ISSR1 primers as in Table 2. Lane $M=$ marker. 


\section{Genetic diversity and cluster analysis}

Jaccard similarity coefficient from the ISSR marker ranged from 0.55 between genotypes of $J$. curcas MÉXICO-A3 and J. integerrima to 0.86 between genotypes L8P29 and L11P7. The average of the 66 accessions was 0.59 . Regarding the geographic regions adopted, the similarity coefficient was 0.63 and 0.58 for Brazilian and Mexican accessions, respectively. The clustering dendrogram of Figure 2 separated the genotypes into two main clusters. The congeneric species $J$. integerrima was clearly separately from all $J$. curcas genotypes. A large group includes all $J$. curcas accessions evaluated as also the backcrosses. The F1 hybrid was assigned to a subcluster between J. integerrima and J. curcas; however, closer to $J$. curcas. In cluster I, the accessions of the different geographical origins did not cluster together. Accessions from Mexico were distributed into several subgroups of dendrograms (Figure 2).

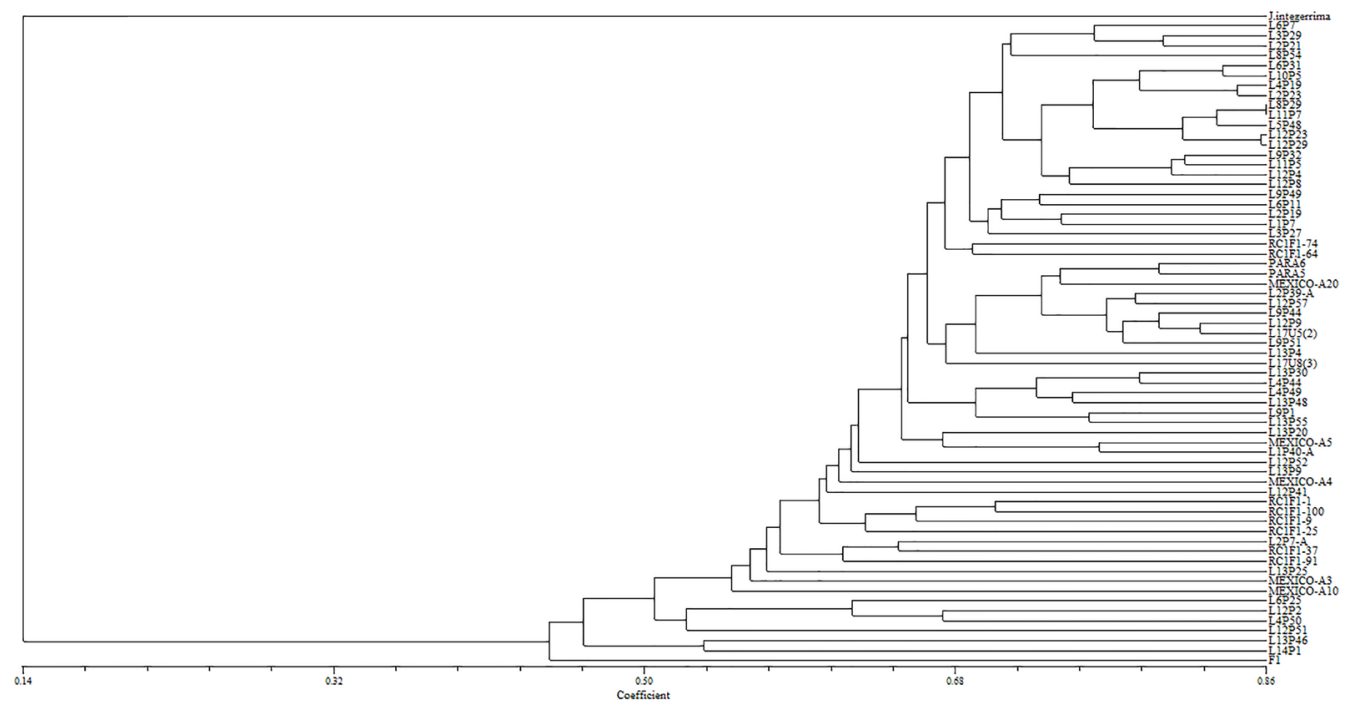

Figure 2. Dendrogram of 66 Jatropha accessions obtained by UPGMA based on Jaccard's genetic similarity coefficient using ISSR data.

\section{Genetic diversity among Jatropha groups}

At the group level proposed in Table 3 and assuming Hardy-Weinberg equilibrium, the total genetic diversity (Nei, 1972) was 0.14 (Table 3). There was a differentiation between groups $\left(G_{\mathrm{ST}}=0.59\right)$ and a high level of gene flow $(\mathrm{Nm}=0.34)$. The genetic structure of the groups (UPGMA) was calculated using the Nei's genetic distance (1972). The dendrogram (Figure 3) shows two main clusters that separate wild species from other genotypes of $J$. curcas. A greater genetic identity was found between the groups from southeastern and northeastern Brazil (0.99). The group of accessions from Mexico was more similar to the Brazilian accessions than to the Chinese group.

Genetics and Molecular Research 16 (2): gmr16029683 


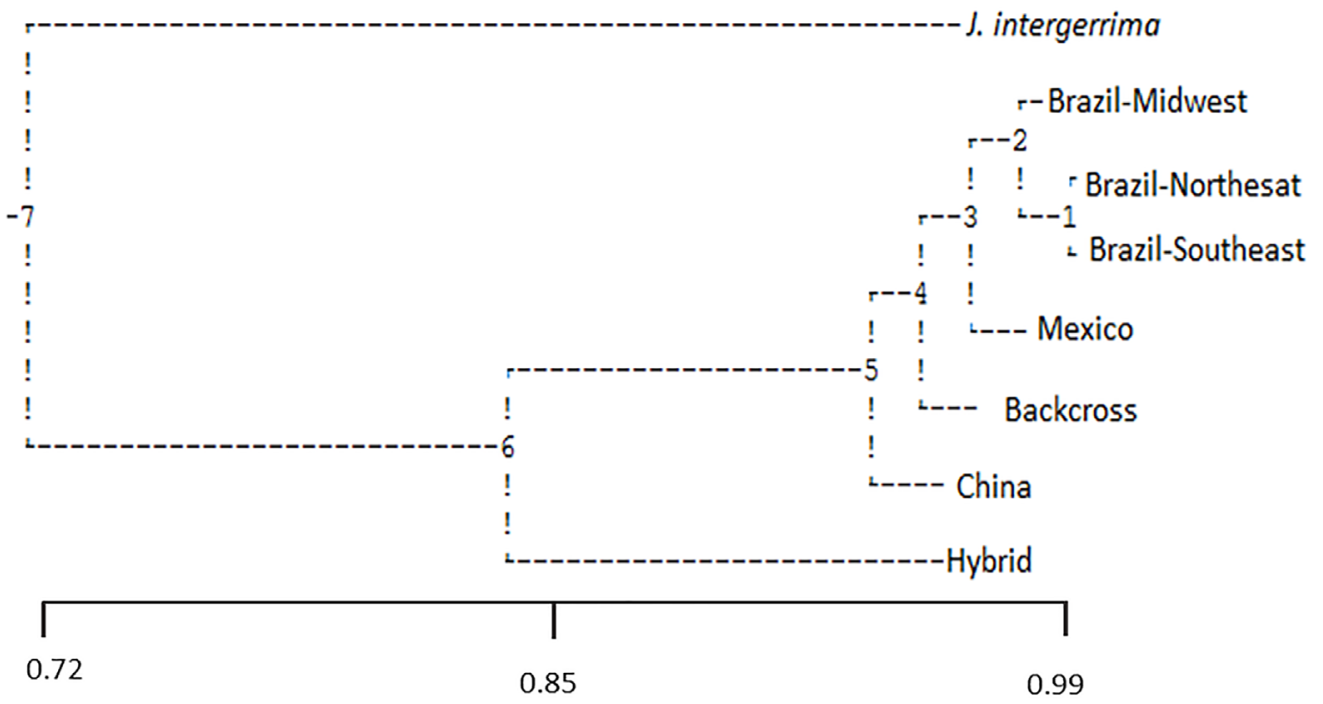

Figure 3. Dendrogram of the Jatropha groups based on Nei's similarity coefficient.

Table 3. Genetic parameters of intra- and intergroup genetic diversity among the five Jatropha groups by ISSR markers.

\begin{tabular}{|c|c|c|c|c|c|}
\hline \multirow[t]{2}{*}{ Group } & \multicolumn{5}{|c|}{ ISSRs } \\
\hline & $\mathrm{N}$ & $N_{\mathrm{A}}$ & $N_{\mathrm{E}}$ & $H$ & $I$ \\
\hline J. integerrima & 1 & 1.00 & 1.00 & 0.00 & 0.00 \\
\hline Brazil midwest & 4 & 1.23 & 1.17 & 0.09 & 0.14 \\
\hline Brazil northeast & 15 & 1.43 & 1.18 & 0.11 & 0.18 \\
\hline Brazil Southeast & 30 & 1.4 & 1.15 & 0.09 & 0.15 \\
\hline Mexico & 5 & 1.23 & 1.15 & 0.09 & 0.13 \\
\hline China & 2 & 1.09 & 1.09 & 0.04 & 0.06 \\
\hline Backcrosses & 8 & 1.31 & 1.2 & 0.11 & 0.17 \\
\hline Hybrid & 1 & 1.00 & 1.00 & 0.00 & 0.00 \\
\hline Total & 66 & 1.76 & 1.19 & 0.12 & 0.20 \\
\hline
\end{tabular}

$\mathrm{N}=$ samples size; $N_{\mathrm{A}}=$ observed number of alleles; $N_{\mathrm{E}}=$ effective number of alleles, Kimura and Crow (1964); $H$ = Nei's (1972) gene diversity; $I=$ Shannon's information index, Lewontin (1972).

\section{Genetic structure of Jatropha spp accessions}

The diversity structuring of the 66 genotypes without a previous hierarchization, using Bayesian analysis revealed three genetic groups $(K=3)$ as shown in Figure 4, where each group was represented by a different color.

Groups I (red) and II (green) showed a partial association of accessions from different geographical regions. The group I was made up of five accessions from three different geographical regions of Brazil, one from Mato Grosso, one from Pernambuco, and tree from São Paulo. The group II was formed by 57 accessions, mainly from Brazil, five accessions from Mexico, two Chinese accessions, and five backcross genotypes. The group III (blue) was clearly distinct by joining the $J$. integerrima, the hybrid F1, one Backcross, and one accession from Pernambuco, Brazil. 
The results of the genetic structure showed that there was not a strong relationship between the genetic structure and the geographical origin. This result was found by the UPGMA analysis. A proportion of genetic recombination was found. For example, accessions 12 (L12P51) and 49 (L14P1), showed a mixture of the three groups, while 38 (L13P48), 46 (L13P55), 36 (L4P44), and 6 (L13P30) exhibited a mixture of groups I and II, in approximately equal proportions and the backcrosses; 58 (RC1F1-1), 59 (RC1F1-91), 61 (RC1F1-25), 62 (RC1F1-9), 64 (RC1F1-37), and 65 (RC1F1-100) were admixed but with a stronger adherence to the $J$. curcas group.

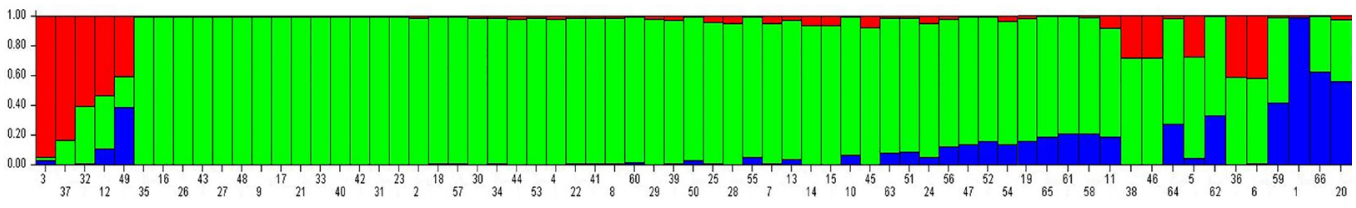

Figure 4. Bayesian admixture proportion of individual accessions of Jatropha spp for a $\mathrm{K}=3$ population model. The groups are indicated by different colors.

\section{DISCUSSION}

The characterization of the genetic diversity of the Jatropha germplasm is critical to establish strategies for conservation and genetic breeding. Molecular markers based on differences in nucleotide sequence are widely applied in studies of germplasm characterization, which allows eliminating the drawbacks of a selection based solely on the phenotypic analysis (Mondini et al., 2009) and have been employed to assess genetic diversity in several studies with Jatropha (Montes et al., 2014; Pecina-Quintero et al., 2014; Pioto et al., 2015; Mavuso et al., 2016).

In this study, ISSR markers were used to characterize the genetic structure and diversity of the germplasm content in J. curcas genotypes from different Brazilian states and countries as well hybrids between $J$. curcas and $J$. integerrima species (F1 and backcross generations).

The ISSR marker was adopted because it can produce multilocus profiles widely spanning the genome even in the absence of prior genetic information (Eguiarte et al., 2007). In the present study, the ISSR markers used detected high levels of locus polymorphism $(98.9 \%)$ with an average of $22.7 \%$ per primer. The high degrees of polymorphism found are comparable with those registered in other studies on Jatropha using ISSR markers (Murty et al., 2013; Mavuso et al., 2016). Besides, the ISSR marker showed to be capable of differentiating the accessions, where the average similarity coefficient was 0.59 . Since ISSR generates high levels of polymorphism, it could be a method of choice for discriminating genotypes closely related and with a narrow genetic base as in the case of $J$. curcas.

The genetic diversity found in the present study was greater than that reported in studies conducted in China (Shen et al., 2010), Malaysia (Sun et al., 2008), India (Mastan et al., 2012), Taiwan (Mavuso et al., 2016), Thailand (Sirisak et al., 2015), and even studies conducted in other germplasm banks in Brazil (Rosado et al., 2010; Grativol et al., 2011; LiraMedeiro et al., 2013; Alves et al., 2013). The genetic diversity among groups analyzed by the Nei's index (1987) was significantly higher (0.12) than that found among Chinese accessions (0.19) as reported by Cai et al. (2010). 
Genetic relationships among accessions are important for selection activities, the formation of work collection, and to direct crosses between accessions with complementary agronomic traits. Dendrogram obtained by the UPGMA method (Figure 2) revealed two major groups at Jatropha germplasm: one made up of wild accession and another group with accessions of J. curcas from Brazil, Mexico, China, and the improved Backcross genotypes. Similar results were reported by Ganesh-Ram et al. (2008). Our dendrogram revealed that Mexican genotypes were not grouped in a separately and single cluster. Instead, they were distributed into different subgroups together with the accessions from different Brazilian states and the two Chinese genotypes, sharing a genetic identity. Although underrepresented in this study, Mexican accessions dispersed in the dendrogram indicate the existence of a wide genetic variability, suggesting that more intensive utilization of Mexican germplasm could allow broadening of diversity in $J$. curcas breeding programs.

The dendrogram showed no clear grouping of the accessions according to geographical origins. Similar results were found by Pazeto et al. (2015); Rosado et al. (2010), and Shen et al. (2010). A lack of correspondence between the molecular classification and geographic origin of the accessions could be due to the possible common origin of accessions. This result was corroborated by the Bayesian analysis, which grouped all the accessions into three major groups with some genetic recombination among groups. Although the large geographical distance between the Brazilian regions, J. curcas accessions representing these regions were gathered in groups I and II (Figure 4) indicating the possibility of allele exchange between accessions of these groups.

Mexico is considered the center of origin of $J$. curcas, which has spread to other continents mainly by the Portuguese during the formation of their colonies (Pamidimarri and Muppala, 2014; Guo et al., 2016). As the center of origin of the species, the germplasm around the world is derived from Mexico, and a high similarity among them is expected. Moreover, the occurrence of migration or exchange of genetic material by human activities, favoring introgression of genes between accessions and the sharing of alleles could explain the lack of a strong genetic structure among the accessions even from different countries.

Genetic diversity among groups estimated by the Nei's index (1987) was higher (0.12) when compared to the values found for Chinese accessions (0.19) reported by Cai et al. (2010). Even, the values were higher (0.28) than those observed by Grativol et al. (2011) for Brazilian accessions. The genetic differentiation coefficient $\left(G_{\mathrm{ST}}=0.59\right)$ indicating that the total variation is due mostly to the distinction between groups rather than among groups. Biabani et al. (2012) verified lower values of differentiation using ISSR and AFLP markers in populations of $J$. curcas from Asia. Gene flow (0.72) estimated was considered low, which favored the group differentiation. These results could be attributed to low levels of crosspollination among groups.

The closest genetic relationships among accessions from the Northeast and Southeast regions of Brazil can be due to the founder effect; a few genotypes gave rise to materials that have spread across the country, mainly through vegetative propagation and consequently fixation of genotypes. Meanwhile, the low diversity among these accessions may also be a result of the selection practice of farmers to obtain plants with higher yield, uniformity, oil content, and other traits of agronomic interest, which associated with vegetative propagation, cause narrowing of the genetic base. The low genetic differentiation among groups represented by genotypes from different regions of Brazil and the group of accessions from Mexico may indicate that Brazilian accessions have originated from the Mexican genetic background, as

Genetics and Molecular Research 16 (2): gmr16029683 
mentioned before and supporter by Pamidimarri and Muppala (2014); Pazeto et al. (2015) and Guo et al. (2016) .

The challenge of all plant genetic breeding programs is to maintain the genetic diversity within the target species while improving desired traits that enable plant materials to perform well. To broaden the genetic diversity of $J$. curcas, interspecific hybridization is presented as a promising method to transfer the diversity conserved in the related species with introgression of desirable traits. This methodology can ensure the success of future breeding improvement programs.

Sudheer et al. (2011) and Sirisak et al. (2015) have identified $J$. integerrima and $J$. gossypiifolia as the most genetically close accessions of $J$. curcas.

One of the approaches for $J$. curcas genetic improvement used by our team was the introgression of genes from related wild species into the genetic background of target $J$. curcas seeking to improve agronomic traits such as biotic and abiotic tolerance. J. integerrima, highly tolerant to pests and disease, was used as male parental genotypes in the crossing aiming the transfer this trait $J$. curcas using backcrosses. The UPGMA (Figure 2) among accessions and groups showed that interspecific hybrid $\mathrm{F} 1$ of the study is closely related to $J$. curcas than $J$. integerrima indicating that the maternal species is the probable donor of the major part of the genome. However, it was separated from the rest of the accessions of J. curcas showing genetic differentiation.

Backcrossing is a breeding strategy to transfer a characteristic from a donor into the genomic background of a recurrent parent. The proportion of genome from the donor parent tends to zero as generations accumulate, except for the part hosting the characteristic of interest. Based on the UPGMA and Structure results, the backcrosses evaluated were genetically closer to the recurrent genitor (J. curcas) as desired to the $J$. curcas plant breeding.

\section{CONCLUSIONS}

The success on breeding programs is largely dependent on understanding the genetic diversity of the germplasm. Various studies using molecular markers had been approaching showing low to moderate genetic diversity in Jatropha germplasm around the world. Our results evidence high genetic diversity in the germplasm evaluated compared whit the germplasm from other countries. The Mexican germplasm and the wild related Jatropha species represented a large and important source to broaden the genetic diversity. Also, the use of $J$. curcas $\mathrm{x} J$. integerrima interspecific hybrid was demonstrated by the ISSR marker as a way to broaden the genetic diversity of $J$. curcas.

Clearly, these findings improved our knowledge about the situation of $J$. curcas diversity in Brazil and led to appropriate information, which is useful for the successful management of germplasm on the breeding programs.

Overall, the present results confirm the usefulness of ISSR markers for characterization and genetic diversity analysis of $J$. curcas accessions.

\section{ACKNOWLEDGMENTS}

Research supported by Petrobras. B.G. Díaz and D.M. de Laat thank Coordenação de Aperfeiçoamento de Pessoal de Nível Superior (CAPES) and C.A. Colombo thanks Conselho Nacional de Desenvolvimento Científico e Tecnológico (CNPq) for granting fellowships.

Genetics and Molecular Research 16 (2): gmr16029683 


\section{REFERENCES}

Alves AA, Bhering LL, Rosado TB, Laviola BG, et al. (2013) Joint analysis of phenotypic and molecular diversity provides new insights on the genetic variability of the Brazilian physic nut germplasm bank. Genet. Mol. Biol. 36: 371-381.

Argollo Marques D, Siqueira WJ, Colombo CA and Ferrari RA (2013). Breeding and Biotechnology of Jatropha curcas. In: Jatropha, Challenges for a New Energy Crop: v. 2: Genetic Improvement and Biotechnology. 1st edn. (Bahadur B, Sujatha M, Carels N, eds.). Springe Science + Business Mediar, New York. http://dx.doi.org/10.1007/978-1-46144915-7 23.

Basha SD and Sujatha M (2007). Inter and intra-population variability of Jatropha curcas (L.) characterized by RAPD and ISSR markers and development of population-specific SCAR markers. Euphytica 156: 375-386 https://doi. org/10.1007/s10681-007-9387-5.

Biabani A, Rafii MY, Saleh G, Shabanimofrad M, et al. (2012). Combining ability analysis and evaluation of heterosis in Jatropha curcas L. F1-Hybrids. Aust. J. Crop Sci. 6: 1030-1036.

Breviario D, Baird WV, Sangoi S, Hilu K, et al. (2007). High polymorphism and resolution in targeted fingerprinting with combined b-tubulin introns. Mol. Breed. 20: 249-259 https://doi.org/10.1007/s11032-007-9087-9.

Cai Y, Sun D, Wu G and Peng J (2010). ISSR-based genetic diversity of Jatropha curcas germplasm in China. Biomass Bioenergy 7: 1-12 10.1016/j.biombioe.2010.07.001.

Doyle JJ and Doyle JL (1990). Isolation of plant DNA from fresh tissue. Focus 12: 13-15.

Earl DA and VonHoldt BM (2012). STRUCTURE HARVESTER: a website and program for visualizing STRUCTURE output and implementing the Evanno method. Conserv. Genet. Resour. 4: 359-361. https://doi.org/10.1007/s12686$\underline{011-9548-7}$

Eguiarte L, Souza V and Aguirre X (2007). Ecología Molecular. 1st edn. Secretaría de Medio Ambiente y Recursos Naturales. Instituto Nacional de Ecología. UNAM, México.

Evanno G, Regnaut S and Goudet J (2005). Detecting the number of clusters of individuals using the software STRUCTURE: a simulation study. Mol. Ecol. 14: 2611-2620 https://doi.org/10.1111/j.1365-294X.2005.02553.x.

Ganesh-Ram S, Parthiban KT, Senthil KR, Thiruvengadam V, et al. (2008). Genetic diversity among Jatropha species as revealed by RAPD markers. Genet. Resour. Crop Evol. 55: 803-809 https://doi.org/10.1007/s10722-007-9285-7.

Grativol C, da Fonseca Lira-Medeiros C, Hemerly AS and Ferreira PC (2011). High efficiency and reliability of intersimple sequence repeats (ISSR) markers for evaluation of genetic diversity in Brazilian cultivated Jatropha curcas L. accessions. Mol. Biol. Rep. 38: 4245-4256 https://doi.org/10.1007/s11033-010-0547-7.

Guo GY, Chen F, Shi XD, Tian YS, et al. (2016). Genetic variation and phylogenetic relationship analysis of Jatropha curcas L. inferred from nrDNA ITS sequence. Comptes Rendus Biologies. Available at [http://www.sciencedirect. com/science/article/pii/S163106911630083X].

Kimura M and Crow JF (1964). The number of alleles that can be maintained in a finite population. Genetics 49: 725-738.

Lewontin RC (1972). Testing the theory of natural selection. Nature 236: 181-182. https://doi.org/10.1038/236181a0

Lira-Medeiro FC, Grativol C and Ferreira PC (2013). Relationship of the genetic diversity of Jatropha curcas in Brazil and worldwide. In: Jatropha, Challenges for a New Energy Crop: v. 2: Genetic Improvement and Biotechnology. 1st edn. (Bahadur B, Sujatha M and Carels N, eds.). Springe Science + Business Mediar, New York. http://dx.doi. org/10.1007/978-1-4614-4915-7_23.

Mastan SG, Sudheer PDVN, Rahman H, Ghosh A, et al. (2012). Molecular characterization of intra-population variability of Jatropha curcas L. using DNA based molecular markers. Mol. Biol. Rep. 39: 4383-4390 https://doi.org/10.1007/ s11033-011-1226-Z.

Mavuso C, Wu YP, Chen FC, Huang B, et al. (2015). Genetic diversity analysis of Jatropha curcas L. accessions cultivated in Taiwan using inter simple sequence repeats (ISSR) markers. Agrofor. Syst. 90: 417-431 https://doi.org/10.1007/ s10457-015-9864-0.

Mondini L, Noorani A and Pagnotta M (2009). Assessing plant genetic diversity by molecular tools. Diversity (Basel) 1: 19-35 https://doi.org/10.3390/d1010019.

Montes MJ, Technow F, Martin M and Becke K (2014). Genetic Diversity in Jatropha curcas L. Assessed with SSR and SNP Markers. Diversity (Basel) 6: 551-566 https://doi.org/10.3390/d6030551.

Montes JM and Melchinger AE (2016). Domestication and Breeding of Jatropha curcas L. Trends Plant Sci. 21: 10451057 https://doi.org/10.1016/j.tplants.2016.08.008.

Montes Osorio LR, Torres Salvador AF, Jongschaap REE, Azurdia Perez CA, et al. (2014). High level of molecular and phenotypic biodiversity in Jatropha curcas from Central America compared to Africa, Asia and South America. BMC Plant Biol. 14: 77. https://doi.org/10.1186/1471-2229-14-77

Murty GS, Patel F, Punwar BS, Patel M, et al. (2013). Comparison of RAPD, ISSR, and DAMD Markers for Genetic

Genetics and Molecular Research 16 (2): gmr16029683 
Diversity Assessment between Accessions of Jatropha curcas L. and Its Related Species. J. Agr. Sci. Tech. 15: 10071022.

Nei M (1972). Genetic distance between populations. Am. Nat. 106: 283-292. https://doi.org/10.1086/282771

Pamidimarri DVNS and Muppala PR (2014). Phylogeography and molecular diversity analysis of Jatropha curcas L. and the dispersal route revealed by RAPD, AFLP and nrDNA-ITS analysis. Mol. Biol. Rep. 41:3225-3234. http:// dx.10.1007/s11033-014-3185-7

Pazeto MSR, Unêda-Trevisoli SH, Corrêa AAP, Vianna VF, et al. (2015) Genetic diversity in Jatropha species from different regions of Brazil based on morphological characters and inters-simple sequence repeat (ISSR) molecular markers. Afr. J. Biotechnol. 14: 2066-2079.

Pecina-Quintero V, Anaya LJL, Zamarripa CA, Núñez CCA, et al. (2014). Genetic structure of Jatropha curcas L. in Mexico and probable center of origin. Biomass Bioenergy 60: 147-155 https://doi.org/10.1016/j.biombioe.2013.11.005.

Pioto F, Costa SR, França CS, Gavioli AE, et al. (2015). Genetic diversity by AFLP analysis within Jatropha curcas L. populations in the State of Sao Paulo, Brazil. Biomass Bioenergy 80: 316-320. https://doi.org/10.1016/j. biombioe.2015.06.014

Popluechai S, Breviario D, Mulpuri S, Makkar HPS, et al. (2009). Narrow genetic and apparent phenetic diversity in Jatropha curcas: initial success with generating low phorbol ester interspecific hybrids. Nat. Proc. London.

Pritchard JK, Stephens M and Donnelly P (2000). Inference of population structure using multilocus genotype data. Genetics 155: 945-959.

Rao GR, Korwar GR, Shanker AK and Ramakrishna YS (2008). Genetic associations, variability and diversity in seed characters, growth, reproductive phenology and yield in Jatropha curcas (L) accessions. Trees (Berl.) 22: 697-709 https://doi.org/10.1007/s00468-008-0229-4.

Rohlf FJ (1989). NTSYS-Pc: Numerical taxonomy and multivariate analysis system. Exeter Software, New York.

Rosado TB, Laviola BG, Faria DA, Pappas MR, Bhering et al. (2010). Molecular markers reveal limited genetic diversity in a large germplasm collection of the biofuel crop Jatropha curcas L. in Brazil. Crop Sci. 50: 2372-2382 https://doi. org/10.2135/cropsci2010.02.0112.

Santos DN, Ferreira JL, Pasqual M, Generoso AL, et al. (2016). Population structure of jatropha and its implication for the breeding program. Genet. Mol. Res. 15: 1-11. https://doi.org/10.4238/gmr.15017770

Shen JL, Jia XN, Ni HQ, Sun PG, et al. (2010). AFLP analysis of genetic diversity of Jatropha curcas grown in Hainan, China. Trees (Berl.) 24: 455-462 https://doi.org/10.1007/s00468-010-0413-1.

Sirisak S, Sripichitt P, Kaveeta R and Hongtrakul V (2015). Assessment of genetic diversity of Jatropha curcas L. using AFLP and ISSR markers. Warasan Khana Witthayasat Maha Witthayalai Chiang Mai 42: 614-625.

Subramanian KA, Singal SK, Saxena M and Singhal S (2005). Utilization of liquid biofuels in automotive diesel engines: An Indian perspective. Biomass Bioenergy 29: 65-72. https://doi.org/10.1016/j.biombioe.2005.02.001

Sudheer PD, Mastan SG, Rahman H, Prakash ChR, et al. (2011). Cross species amplification ability of novel microsatellites isolated from Jatropha curcas and genetic relationship with sister taxa: cross species amplification and genetic relationship of Jatropha using novel microsatellites. Mol. Biol. Rep. 38: 1383-1388 https://doi.org/10.1007/s11033010-0241-9.

Sun QB, Li LF, Li Y, Wu GJ, et al. (2008). SSR and AFLP markers reveal low genetic diversity in the biofuel plant: Jatropha curcas in China. Crop Sci. 48: 1865-187 https://doi.org/10.2135/cropsci2008.02.0074.

Tanya P, Taeprayoon P, Hadkam Y and Srinives P (2011). Genetic diversity among Jatropha and Jatropha related species based on ISSR markers. Plant Mol. Biol. Report. 29: 252-264 https://doi.org/10.1007/s11105-010-0220-2.

Yeh FC, Yang RC and Boyle T (1999). POPGENE Version 1.3.2. Microsoft Window-based Freeware for Population Genetic Analysis. Molecular Biology and Biotechnology Center, University of Alberta, Edmonton.

Genetics and Molecular Research 16 (2): gmr16029683 